\title{
Linear Smoke Detectors in Fire Protection
}

\author{
RADOJE B. JEVTIĆ, Electrotechnical school „Nikola Tesla“, Niš
}

\author{
Professional paper \\ UDC: 614.84
}

DOI: 10.5937/tehnika2104529J

\begin{abstract}
Smoke detectors generally present the most frequently used fire detectors. These detectors have great appliance because smoke presents the consequence of many fires. These detectors can be realized as point smoke detectors and linear smoke detectors, while special smoke detectors are used for special purposes. Their efficiency is the biggest in the cases where fuel material produces smaller or larger amounts of smoke. The use of smoke detectors in the form of linear smoke detectors is particularly significant in rooms with huge dimensions and huge ceiling height. This paper was written to present work principle of linear smoke detectors and their installation in objects related to valid standards (EN 54, BS, НПБ 88-2001, VDE 088-2 and NFPA 72).
\end{abstract}

Key words: linear, smoke, detector, standard, fire

\section{INTRODUCTION}

In many cases of fire, smoke is the first detection product that can be used. Smoke presents the suspension of solid and liquid particles in gaseous environment. These particles can be with different dimen-sions, mostly very small (from nm to $\mu \mathrm{m}$ ), depending on fuel material. Because of that fact, smoke detectors are realized to examine the optical characteristics of smoke. Related to International standard ISO 7240-9: Test fires for fire detectors, there are nine different classes of fires, noted as TF1, TF2, to TF9. Most of them (eight classes) have smoke as product.

Smoke detectors available on the market are mostly in the form of point smoke detectors, linear smoke detectors and special smoke detectors for special purposes. Point smoke detectors were realized as ionization smoke detectors and photoelectric smoke detectors. Ionization smoke detectors use radioactive element for their work. Photoelectric smoke detectors use two principles for their work: principle of reflection (light scattering reflected light smoke detectors) and principle of absorption (light obscuration smoke detectors). Point smoke detectors sensitivity depends from particles dimension. Ionisation smoke detectors are more appropriate for smoke detection with smaller pa-

Author's address: Radoje Jevtić, Electrotechnical school „Nikola Tesla“, Niš, Aleksandra Medvedeva 18

e-mail: milan.jvtc@gmail.com

Paper received: 24.06.2021.

Paper accepted: 29.06.2021. rticles while photoelectric smoke detectors are more appropriate for smoke detection with bigger particles. The installation of smoke detectors is defined by valid standards and manuals of manufacturers. The main principle for installation in object is that smoke detectors with their covering ranges cover the entire object's area.

During exploitation of point smoke detectors, the optics of detectors becomes dirty. The price of point smoke detectors is not enough to provide appropriate electronic dirtiness compensation. Linear smoke detectors are capable to cover 15 times bigger area then point smoke detectors and their price enables appropriate electronic dirtiness compensation. These detectors are less sensitivity to smoke colour, so this fact makes them very appropriate in situations where black smoke is expected. Also, linear smoke detectors are particularly suitable in objects with huge dimensions and huge ceiling height, such as atria, libraries, warehouses etc $[1,3,7]$.

\section{LINEAR SMOKE DETECTORS-WORK PRINCIPLE}

The main principle of linear smoke detectors is an absorption. This purport measuring of light intensity attenuation as a consequence of smoke. Linear smoke detectors are mostly realized in form of transmitter, receiver and control part. In constructive sense, these elements can be separate or in the same whole. Transmitter serves to product infrared light beam to the receiver. The dimensions of infrared beam are several 
hundreds of nano metes. Infrared beam purports that no cables are necessary between transmitter and receiver. Receiver with photosensitive sensor proceeds this beam to the control unit. The role of the transmitter is to create and emit infrared beam to receiver or to the mirror. In the case of receiver, this infrared beam creates signal on receiver's photodiode. In the case of mirror, infrared beam comes to the mirror and comes back to the transmitter. In both cases, in the presence of smoke, signal will weaken what will lead to alarm occurrence. The most of linear smoke detectors have possibility to set alarm threshold. The threshold presents obscuration percentage and depends from manufacturer. The dimensions of particles that can be detected by linear smoke detectors are few micro meters.

It is very important that transmitter and receiver or mirror are installed on background that is immune to vibrations. As an example, in the case of transmitter's displacement of several tenths of one degree, the beam will be displaced at the distance of $100 \mathrm{~m}$ for several tenths of meter. These detectors are intended for installation in objects where disturbances that can interrupt light beam are not expected. Changes on lenses caused by dirt can be compensated to some extent.

Linear smoke detector in variant transmitter-receiver and variant with the mirror are presented on figures 1 and 2.

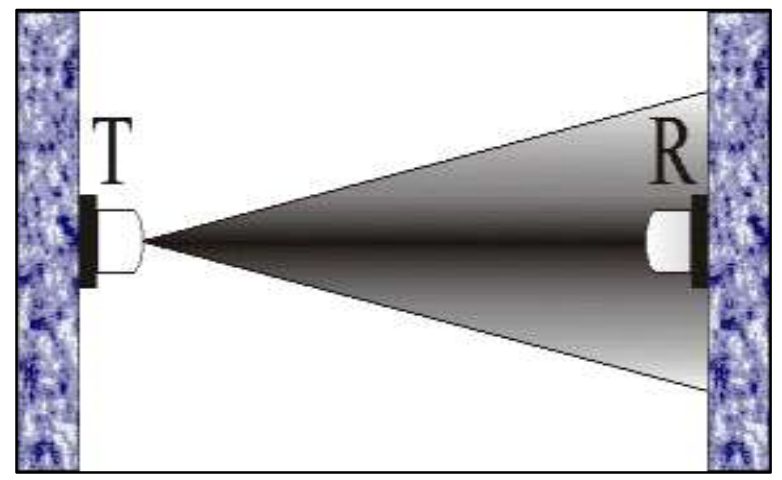

Figure 1 - Linear smoke detector in variant transmitter-receiver

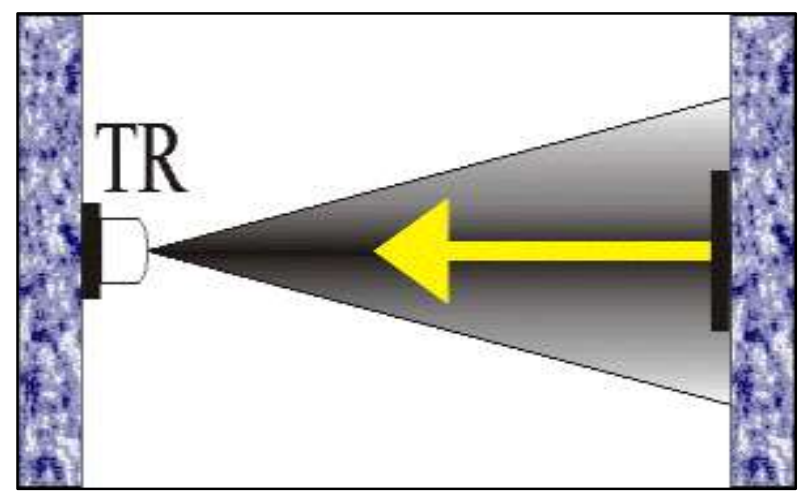

Figure 2 - Linear smoke detector in variant with the mirror
The efficiency of this detectors significantly depends from occurrence known as stratification. Stratification occurs when the smoke temperature equals to surrounding air temperature. This occurrence is particularly pronounced in the absence of ventilation. The forms of stratification can be different and related to that fact, the installation of line smoke detectors on different heights must be considered. The simulation of stratification in FDS is presented on figure $3[1,2$, $4,8]$.

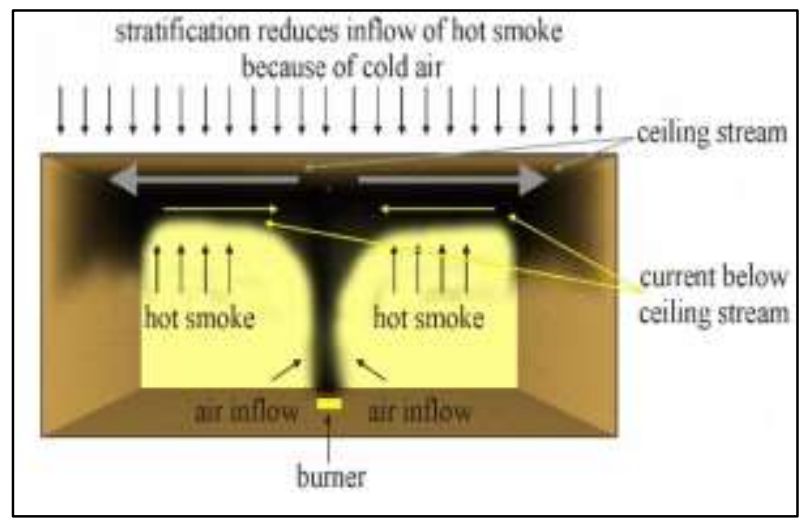

Figure 3 - Simulation of stratification in FDS

\section{RULES FOR INSTALLATION OF LINEAR SMOKE DETECTORS}

There are three basic rules for linear smoke detectors installation. The reason for applying these rules is that because fire cannot be predicted. These rules purport diagonal installation of linear smoke detectors, horizontal installations of linear smoke detectors at different levels for particularly smoke layers detection and horizontal installations of linear smoke detectors in the top of the flame.

Diagonal installation of linear smoke detectors purports detectors directed to the ceiling. The purpose of this way of linear smoke detectors installation is in fast detection of smoke layer development, no matter on fire temperature. Diagonal installation of linear smoke detectors demands existence of two or more linear smoke detectors.

Horizontal installation of linear smoke detectors at different levels for particularly smoke layers is applicable in cases when the height where the stratification will be occurred cannot be predicted. The height of installation for detectors is defined by valid standards.

Horizontal installations of linear smoke detectors in the level of the flame's top is intended to detect smoke appearance in the level of the flame`s top. This realisation demands installation of several levels of line smoke detectors at specific height. This height pre-sents $25 \%$ from the first line smoke detector installed above the floor level. It is necessary that one or more detectors be installed below ceiling level. 
Related to the financial aspect, it is important to note that one linear smoke detector can change bigger number of point smoke detectors. This fact is parti-cularly important in the presence of air flows that doesn't affect on linear smoke detectors efficiency. As a comparation, one linear smoke detector covering surface of $1500 \mathrm{~m}^{2}$, while the same surface requests 15 -point smoke detectors with covering radius of $7.5 \mathrm{~m}$ what is presented on figure 4 .

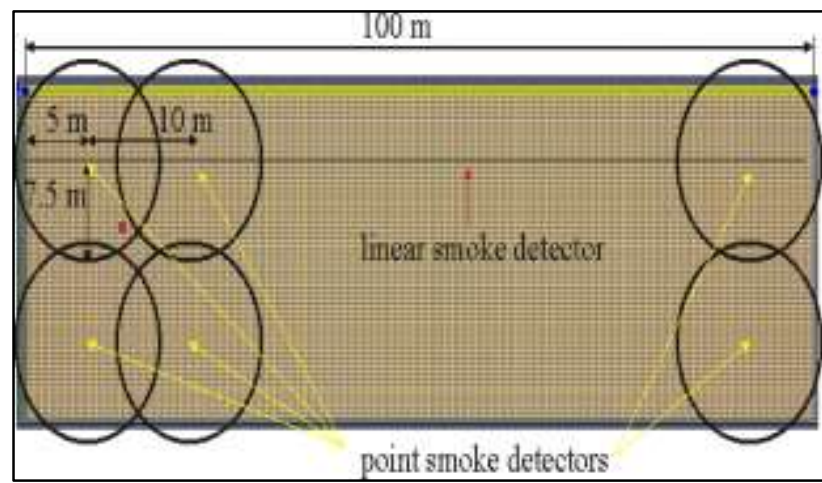

Figure 4 - The comparation of surface covering between linear smoke detector and point smoke detectors

In the comparative simulation in FDS software, where object was protected with point smoke detectors and linear smoke detectors, results showed that the closest point smoke detector and linear smoke detector reacted almost at the same time. As the amount of smoke increased, so did the number of point smoke detectors that responded. But, after some time there were a lot of point smoke detectors that haven't reacted because smoke hasn't come to their reaction ranges. The burner that simulated fire was positioned at $5 \mathrm{~m}$ far away from the left wall, in the middle between upper and lower walls with $100 \mathrm{~m}$ length. The HRR (Heat release rate per area) of burner was $5000 \mathrm{~kW} / \mathrm{m}^{2}$, while the dimensions of the burner were $1 \mathrm{~m} \mathrm{x} 1 \mathrm{~m}$. The simulation of fire after 156 seconds and smoke progression in object in FDS are presented on figure 5.

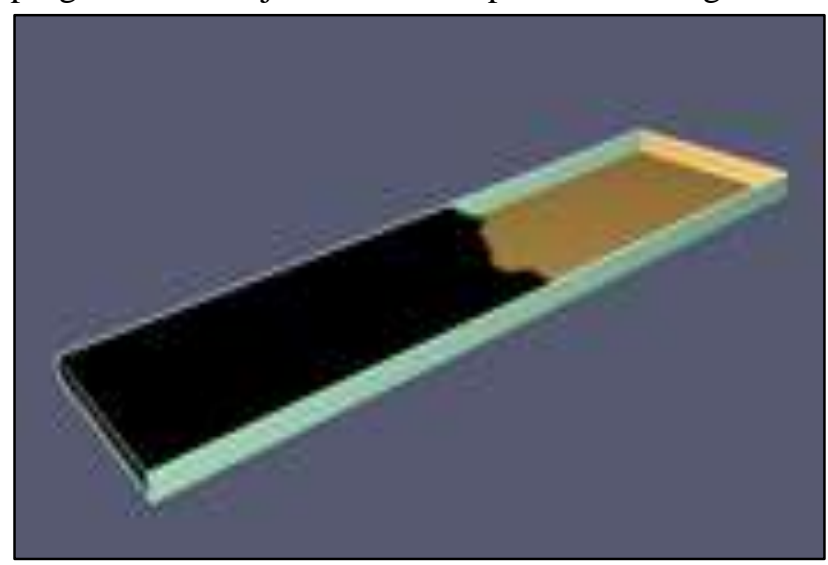

Figure 5 - Simulation moment after 156 seconds from simulation start in FDS
European standard EN 54-14 has the same way of definition for linear smoke detectors covering radius and point smoke detectors covering radius. Related to this standard, covering radius of linear smoke detector is $7.5 \mathrm{~m}$ for ceiling heights up to $11 \mathrm{~m}$. For heights from $11 \mathrm{~m}$ to $25 \mathrm{~m}$, it is necessary to install other level of detectors, while for heights upper than $25 \mathrm{~m}$ this detector is not applicable. In the case where protected area doesn't have ceiling, this standard recommends that covering radius should be $12.5 \%$ from the detector`s height above the highest point where fire can occur.

German standard VDE 0833-2 has some differences related to European standard. The most important factor is the height of the room or space that should be protected. Related to this factor, covering area and maximal mutual distance between optical axes of detectors were defined. It is also important that optical axe of linear smoke detector must be located at least $0.5 \mathrm{~m}$ far from the wall and different obstacles (de-vices, equipment, different stuff etc.). The maximal distance between transmitter and receiver of the linear smoke detector, related to this standard, is up to $100 \mathrm{~m}$. These rules are presented in table 1. Height of the ceiling is marked as $R_{H}$, covering area is marked as $A$, covering radius is marked as $D_{H}$ while allowed values of height below the ceiling where line smoke detectors should be installed are marked as $D_{L}$ (these values are recommended because of stratification).

Table 1. VDE 0833-2 standard recommended values for height of ceiling, covering area and covering radius (table source: Blagojević ĐM. Fire pro-tection systems designing, pp.157)

\begin{tabular}{|l|l|l|l|l|}
\hline \multirow{2}{*}{$\mathrm{R}_{\mathrm{H}}[\mathrm{m}]$} & \multirow{2}{*}{$\mathrm{D}_{\mathrm{H}}[\mathrm{m}]$} & \multirow{2}{*}{$\mathrm{A}\left[\mathrm{m}^{2}\right]$} & \multicolumn{2}{|l|}{ Roof slope } \\
\cline { 4 - 5 } & & & $\alpha \leq 20^{\circ}$ & $\alpha>20^{\circ}$ \\
\cline { 4 - 5 } & & & $\mathrm{D}_{\mathrm{L}}[\mathrm{m}]$ & $\mathrm{D}_{\mathrm{L}}[\mathrm{m}]$ \\
\hline up to 6 & 1200 & 0.3 to 0.5 & 0.3 to 0.5 \\
\hline $\begin{array}{l}\text { between } 6 \\
\text { and 12 }\end{array}$ & 6.5 & 1300 & 0.4 to 0.7 & 0.4 to 0.9 \\
\hline $\begin{array}{l}\text { between } 12 \\
\text { and } 16^{*}\end{array}$ & 7 & 1400 & 0.6 to 0.9 & 0.8 to 1.2 \\
\hline $\begin{array}{l}\text { between } 16 \\
\text { and } 20^{* *}\end{array}$ & 7.5 & 1500 & 0.8 to 1.1 & 1.2 to 1.5 \\
\hline
\end{tabular}

*for heights bigger that $12 \mathrm{~m}$, the recommendation is to install the second level of line smoke detectors related to ceiling height;

\section{**approved in order to increase detection potential}

This standard also noted that linear smoke detectors must be installed on solid construction elements, without potentials of vibrations, reflections from other surfaces and breaking of optical axe.

British standard BS 5839-5 (Part 5: Specification for optical beam detector) recommends that the ma- 
ximal installation height for line smoke detector should be $40 \mathrm{~m}$, but only in special cases. In general cases, the maximal installation height for linear smoke detectors is $25 \mathrm{~m}$. The first part of this standard, marked as BS 5839 Part 1, recommends that linear smoke detectors should be installed related to manufacturer's manual. It is interesting that this standard allows that optical axe of the linear smoke detector can be less than $0.5 \mathrm{~m}$, related to the wall. Minimal distance between trans-mitter and receiver is up to $3 \mathrm{~m}$, while the maximal distance between transmitter and receiver can be up to 100 $\mathrm{m}$. For areas with people presence, the minimal height of installation is $2.7 \mathrm{~m}$.

Russian standard НПБ 88-2001 has differences related to distance between optical axes. The distance between optical axes is particularly defined for heights up to $12 \mathrm{~m}$ and particularly for heights from $12 \mathrm{~m}$ to 18 $\mathrm{m}$, as it is presented in table 2 . It is important to note that height of protected area presents factor of limitation.

Table 2. Covering radius related to the ceiling height, standard НПБ 88-2001 recommendations (table source: Blagojević, Đ. M.: Fire protection systems designing, pp.165).

\begin{tabular}{|l|l|l|}
\hline $\begin{array}{l}\text { Ceiling height } \\
\text { [m] }\end{array}$ & $\begin{array}{l}\text { Maximal distance } \\
\text { of detection point } \\
\text { from optical axe } \\
\text { [m] }\end{array}$ & $\begin{array}{l}\text { Maximal distance } \\
\text { of optical axe } \\
\text { from the wall }[\mathrm{m}]\end{array}$ \\
\hline up to 3.5 & 9.0 & 4.5 \\
\hline from 3.5 to 6 & 8.5 & 4.0 \\
\hline from 6 to 10 & 8.0 & 4.0 \\
\hline from 10 to 12 & 7.5 & 3.5 \\
\hline
\end{tabular}

This standard also recommends that for rooms with height from $12 \mathrm{~m}$ to $18 \mathrm{~m}$ two levels of linear smoke detectors should be installed. The first line of linear smoke detectors should be installed on distance from $1.5 \mathrm{~m}$ to $2 \mathrm{~m}$ above fire source and at least $4 \mathrm{~m}$ from the floor level. The second level of linear smoke detectors should be installed at least $0.4 \mathrm{~m}$ from the ceiling. For both levels, the maximal distances bet-ween optical axes should be $7.5 \mathrm{~m}$, while the maximal distance of optical axe from the wall should be $3.5 \mathrm{~m}$.

American standard NFPA 72 accents that linear smoke detectors should be installed on such way that combustion products break optical axe of at least one linear smoke detector. Because of that fact, this standard recommends that smoke spreading above fire source should be calculated as a function of height that linear smoke detector was installed on. The space of uniform distribution of temperature and smoke density above fire source is spreading on angle of $22^{\circ}$. So, the installation of linear smoke detector is recommended exactly in that space, directly below the area where combustion products form the smoke layer as a consequence of stratification. False alarms could be caused with the presence of dust and vapour in the beam. The smoke spreading and forming of layer of combustion products, as a consequence of stratification realized as simulation in FDS software is presented on figure $6[1,2,4]$.

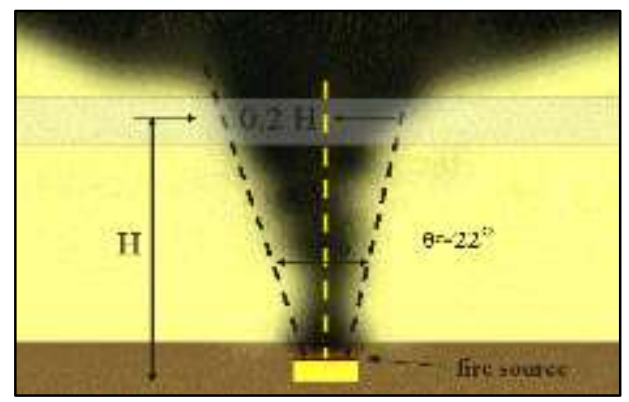

Figure 6 - Simulation of smoke spreading in FDS

\section{INSTALLATION OF LINEAR SMOKE DETECTORS IN SPECIAL CASES}

Linear smoke detectors also can be used in special cases. These cases purport object with special form of ceiling and roof. It is important to note that none of standards don't processing those cases. Because of that, manufacturer`s manuals must be considered.

Special case of linear smoke detector installationsaw form roof is presented on figure 7 .

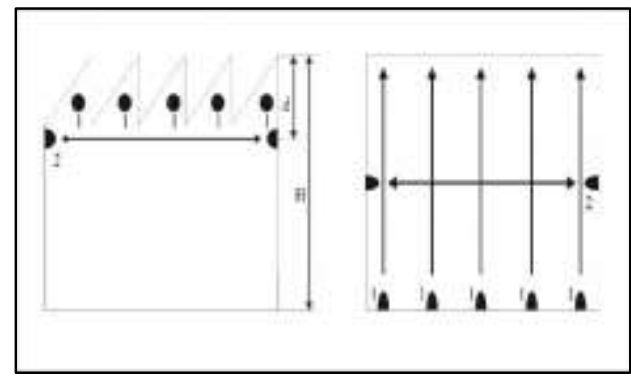

Figure 7 - Special case of linear smoke detector installation-saw form roof (side and above view)

In the case of saw form roof, related to the manufacturer's manual, the linear smoke detector on position marked as 2 is unnecessary if the condition formulated as $\mathrm{d}>0.2 \times \mathrm{H}$ realised.

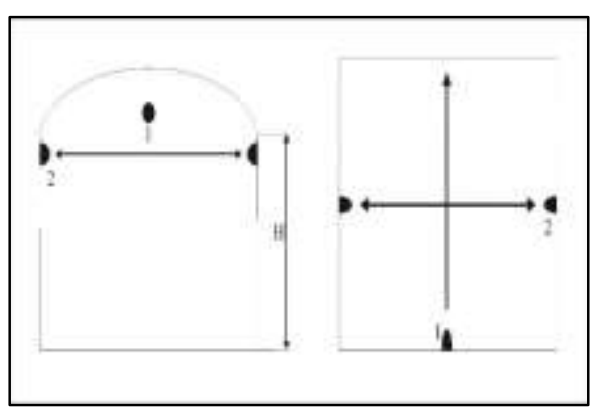

Figure 8 - Special case of linear smoke detector installation-cylinder form roof (side and above view) 
Special case of linear smoke detector installationcylinder form roof is presented on figure 8 .

In the case of cylinder form roof, both positions marked as 1 and 2 are acceptable for installation of linear smoke detectors.

Special case of linear smoke detector installationspherical form roof is presented on figure 9 .

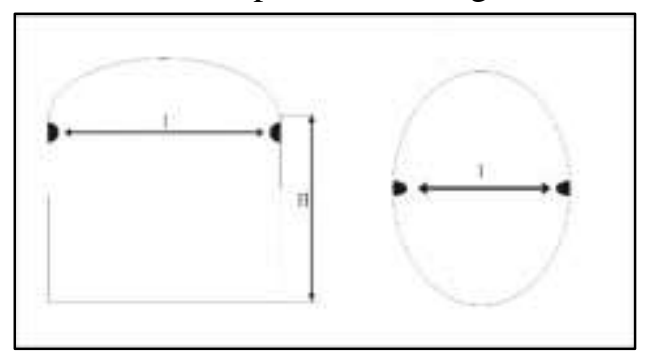

Figure 9 - Special case of linear smoke detector installation-spherical form roof (side and above view)

In the case of spherical form roof, the only one linear smoke detector marked as 1 is enough.

It is important to note that there is one rule that connects installation height and distance between optical axes. This rule can be found in standards and it purports that distance from every side of linear smoke detector`s optical axe should be calculated as $12.5 \%$ related to installation height $[1,2,5,6]$.

\section{CONCLUSION}

Linear smoke detectors present very important type of fire detector and very applicable. These detectors are particularly proper in rooms with huge dimensions, especially huge ceiling height. There are lot of manufacturers of linear smoke detectors on the market today. Those manufacturers product linear smoke detectors related to directions from valid standards, but, for special cases and special purposes, enable huge manuals for their installation and use.

The basic aim of this paper was to present linear smoke detectors, their work principle and their in- stallation in objects related to valid standards. Theoretical postulates related to stratification, reaction speed and space covering are confirmed in FDS simulation software.

\section{REFERENCES}

[1] Blagojević Đ. M. Alarm systems, Faculty of occupational safety in Niš, ISBN 978-86-6093-025-7, pp. 55, 56, 114-116, Niš, 2015.

[2] Blagojević Đ. M. Fire protection systems designing, AGM Book, ISBN 978-86-86363-89-3, Beograd, pp. 159-168, 2018.

[3] Blagojević M, Jevtić R, Ristić D. Comparative Analysis Of Rules For Smoke Detectors Placement In Five Leading Standards, 18 International Con-ference Man \& Working Environment, Faculty of Oc-cupational safety in Niš, Niš, Serbia, 06-07.12.2018.

[4] McGrattan K, Hostikka S, McDermott R, Floyd J, Weinschenk C, Overholt K. Fire Dynamics Simulator Users Guide, NIST Special Publication 1019, Sixth Edition, 288 p., 2013.

[5] HOCHIKI. Photoelectric reflective beam detector, Installation instructions, pp 17-19, 1999.

[6] Jevtić B. R, Blagojević Đ. M. Point Fire Detectors Arrangement in Special Cases-The slope Roofs case, Int. Journal of Engineering Research and Appli-cation, ISSN 2248-9622, Vol. 8, Issue 3, (Part-3), pp. 21-27, March 2018.

[7] Jevtić B. R, Blagojević M. Smoke and Heat Detectors Arrangement in Hallways, Safety Engineering, Vol. 7, No. 2, pp. 21-26, ISSN-2217-7124, Niš, Serbia, 2017.

[8] Jevtić B. R. Material for the preparation of the professional exam in the field of fire protection, Gradski Vatrogasni Savez Niš, pp. 543, 544, 2019.

\section{REZIME}

\section{LINIJSKI DETEKTORI DIMA U ZAŠTITI OD POŽARA}

Detektori dima generalno predstavljaju najkorišćenije detektore požara. Ovi detektori imaju veliku primenu zato što dim predstavlja posledicu mnogih požara. Ovi detektori mogu biti u obliku tačkastih detektora dima i linijskih detektora dima, dok se specijalne vrste detektora dima koriste u specijalne svrhe. Njihova efikasnost je najveća u slučajevima gde gorivi materijal proizvodi manje ili veće količine dima. Upotreba detektora dima u obliku linearnih detektora dima je posebno značajna u prostorijama velikih dimenzija $i$ visoke tavanice. Ovaj rad je napisan da predstavi princip rada linijskih detektora dima i njihovoj instalaciji u objektima prema validnim standardima (EN 54, BS, HПБ 88-2001, VDE 088-2 i NFPA 72).

Ključne reči: linijski, dim, detektor, standard, požar 